\title{
Homestead pond polyculture can improve access to nutritious small fish
}

\author{
Sarah A. Castine ${ }^{1}$ - Jessica R. Bogard ${ }^{2,3}$ • Benoy K. Barman ${ }^{2} \cdot$ Manjurul Karim $^{2}$ • \\ Md. Mokarrom Hossain ${ }^{2}$ - Mrityunjoy Kunda ${ }^{4}$ - A. B. M. Mahfuzul Haque ${ }^{2}$. \\ Michael J. Phillips ${ }^{5}$. Shakuntala H. Thilsted ${ }^{6}$
}

Received: 21 September 2015 / Accepted: 5 June 2017 / Published online: 16 July 2017

(C) Springer Science+Business Media B.V. and International Society for Plant Pathology 2017

\begin{abstract}
In Bangladesh, homestead pond aquaculture currently comprises a polyculture of large fish species but provides an ideal environment to integrate a range of small fish species. Small fish consumed whole, with bones, head and eyes, are rich in micronutrients and are an integral part of diets, particularly for the poor. Results from three large projects demonstrate that the small fish, mola (Amblypharyngodon mola) contributes significantly to the micronutrients produced from all fish, in homestead ponds, in one production cycle. Mola contributed $98 \%, 56 \%$ and $35 \%$ of the total vitamin A, iron and zinc produced, respectively, despite comprising only $15 \%$ of the total fish production by weight. If consumed within the household, mola could contribute half of the vitamin A and a quarter of the iron intake recommended for a family of four, annually. Homestead ponds are uniquely accessible to women who prepare the household food. Further
\end{abstract}

Sarah A. Castine

sarahcastine11@gmail.com

Jessica R. Bogard

J.Bogard@cgiar.org

Benoy K. Barman

b.barman@cgiar.org

Manjurul Karim

m.karim@cgiar.org

Md. Mokarrom Hossain

md.hossain@cgiar.org

Mrityunjoy Kunda

kunda.sau@gmail.com

A. B. M. Mahfuzul Haque

a.haque@cgiar.org

Michael J. Phillips

m.phillips@cgiar.org dissemination of the carp-small fish technology provides opportunities to target women and men together for training on fish production and consumption, nutrition and gender equity. Women only training is also recommended to enable them to engage fully, without feeling dominated by men. Partnering with the fisheries and health sectors will encourage sustainable uptake of this promising technology. Clearly, dissemination could have significant health benefits; however, improved monitoring and evaluation, particularly of dietary diversity and diet quality are essential. Research priorities should also include the production techniques of other small indigenous fish species (SIS), besides mola, and the power dynamics between women and men in operating homestead ponds.

Keywords Small fish $\cdot$ Nutrition $\cdot$ Small-scale aquaculture

Shakuntala H. Thilsted

s.thilsted@cgiar.org

1

Marine Solutions, 110 Swanston Street, New Town, Tasmania 7008, Australia

2 WorldFish, House 22B, Road 7, Block F, Banani, Dhaka 1213, Bangladesh

3 School of Public Health, University of Queensland, Brisbane, QLD, Australia

4 Department of Aquatic Resource Management, Sylhet Agricultural University, Sylhet 3100, Bangladesh

5 WorldFish, Jalan Batu Maung, 11960 Bayan Lepas, Penang, Malaysia

6 WorldFish, House 35, Street 71, Sangkat Boeung Keng Kang 1, Khan Chamkar Morn, Phnom Penh, Cambodia 


\section{Introduction}

Homestead pond aquaculture is prevalent throughout Bangladesh where over four million households own ponds in the vicinity of the homestead, covering an area of 266,259 ha in 2010 (Belton and Azad 2012). Ponds play a crucial role in providing both household income and fish for consumption, contributing between 3 and $15 \%$ of total household income and $25-50 \%$ of total fish consumption (Belton and Azad 2012). Pond polyculture systems have little diversity and are usually optimised to produce 5-10 large fish species, commonly bighead carp (Hypopthalmichthys nobilis), catla (Catla catla), common carp (Cyprinus carpio), mrigal (Cirrhinus cirrhosis), rohu (Labeo rohita), and silver carp (Hypophthalmichthys molitrix). In contrast, a large diversity of fish species (more than 270), particularly small indigenous fish species (SIS, growing to a maximum length of $25 \mathrm{~cm}$ ) are available from inland capture fisheries. Unlike large fish, many of these SIS, which are consumed whole with head and bones, provide a significant source of bioavailable calcium, zinc, iron and vitamin A (Bogard et al. 2015; Roos et al. 2007a). Combining SIS with large species in homestead pond polyculture, offers opportunity to increase household dietary diversity and micronutrient intake (Bogard et al. 2015; Thilsted 2012a).

Ponds adjacent to the homestead offer an ideal opportunity for women to engage and participate in fish culture, in contrast to other forms of aquaculture and capture fisheries, from which women are often excluded due to cultural and social barriers and due to their being located away from the homestead (Sultana and Thompson 2008). Integrating small fish into homestead pond polyculture systems gives women, who do the food preparation, access to nutritious small fish (Thilsted 2012b). Improved access to nutrient-rich foods for pregnant and lactating women and infants and young children, i.e. the first 1000 days of life from conception until the child is two years of age, is known to promote optimal growth, development and cognition, which leads to improved learning, productivity and economic gain (Michaelsen et al. 2011; Victora et al. 2008; Dewey and Vitta 2013).

In Bangladesh, inclusion of SIS in carp polyculture systems in stand-alone ponds and ponds connected to rice fields is currently being promoted as a means to enhance productivity, income and food and nutrition security of the rural poor (Thilsted and Wahab 2014b). However, scale out of these technologies has been limited to date. This is likely to be partly due to a lack of comprehensive, synthesized evidence of the economic and health benefits of carp-SIS polyculture, and its potential contribution to food and nutrition security. In this paper, we address this gap by synthesizing the evidence from the published literature (section 2), and three WorldFishled projects which are currently disseminating the carp-SIS polyculture technology in Bangladesh (section 3). This evidence is essential for garnering appropriate investment and political commitment for scale out of this promising technology, not just in Bangladesh but throughout Asia and abroad.

\section{Literature review}

\section{Development of homestead pond carp-SIS polyculture technology}

Efforts to culture and breed SIS in Bangladesh began in the 1980s (Roos et al. 2007b). A series of small-scale trials demonstrated extremely high production in systems without large fish, ranging between 1.5-8.0 $\mathrm{t}$ per ha per season, of either mixed or monoculture SIS, comprising mainly chapila (Gudusia chapra), dhela (Osteobrama cotio cotio), mola (Amblypharyngodon mola) and puti (Puntius sophore) (Ameen et al. 1984; Felts et al. 1996; Piska and Waghray 1986; Rajts et al. 1997). These trials were run in systems without large fish because during this period, SIS were considered 'weed' or 'trash' fish in carp ponds and were typically poisoned prior to stocking due to the now disproven assumption that they competed with carp for food.

In the 1990s, rigorous research was initiated on carp-mola polyculture in 84 seasonal household ponds (Roos 2001). Later, different trials continued in ponds with mixed carp species and other small fish (Kadir et al. 2006; Kohinoor et al. 2001; Kunda et al. 2009; Milstein et al. 2009; Roos et al. 2007b; Roy et al. 2002; Roy et al. 2003; Wahab et al. 2011). Notably, mola was the predominant SIS used in early trials, although there was some work on developing production technologies suitable for chela (Chela cachius), puti and to a lesser extent, darkina (Esomus danricus) (Kadir et al. 2006; Kohinoor et al. 2001; Roos et al. 2002a; Roy et al. 2002; Roy et al. 2003). The focus on mola in carp-SIS polyculture was due to the extremely high vitamin A content and therefore the potential for mola production as a food-based approach to combat the high prevalence of vitamin A deficiency in Bangladesh (ICDDR et al. 2013). Trials demonstrated that not only was there a lack of competition between mola and carp, but inclusion of mola had the potential to increase overall pond productivity in some cases, thereby increasing quantity and nutritional quality of the total homestead pond system. Furthermore, mola was found to possess several desirable characteristics from an aquaculture perspective. Mola has fast growth rates and high fecundity, reaching sexual maturity in approximately 4-5 months and reproducing two to three times per annum producing approximately 5000 eggs (Azadi and Mamun 2004; Hoque and Rahman 2008; Suresh et al. 2007). Mola is mostly herbivorous and is easily sustained by the natural algal community, particularly chlorophyceae, present in ponds (Gupta and Banerjee 2013; Mamun et al. 2004). 
Evidence of the production, income and nutrition benefits of stand-alone carp-SIS polyculture ponds are summarized below and in Table 1.

\section{Production, income and nutrition}

Thirteen studies were conducted across Bangladesh between 2002 and 2011, investigating different aspects of carp-SIS production in stand-alone homestead ponds (Table 1). Half of these studies were conducted on farm (Kunda et al. 2010, 2009; Roos et al. 2002b, 2003; Roy et al. 2002, 2003; Wahab et al. 2011) and half were controlled field experiments, with a limited number $(n=3-5)$ of replicates (Alim et al. 2004, 2005; Kadir et al. 2006; Milstein et al. 2006, 2009; Wahab et al. 2003). All studies quantified fish production and five reported on income from fish production. Two studies measured impacts on fish consumption habits. Only one study disseminated the technology more broadly (Wahab et al. 2011), and none of these studies measured nutritional outcomes.

For the purpose of comparison among studies, units of production and income have been standardized to tonne $(t)$ per ha per seven months or USD per ha per seven months. Seven months was chosen as it appears to be the standard length of a production cycle, with water remaining in most ponds for approximately this time period.

\section{Production}

Total production from carp-SIS polyculture ponds ranged from 2.2 to $4.4 \mathrm{t}$ per ha per seven months. On average, SIS contributed $7 \%$ of the total fish production ranging from 0.1 to $0.4 \mathrm{t}$ per ha per seven months (Table 1). No studies were conducted to investigate the impact of increasing the proportion coming from small fish. These studies confirmed again that stocking mola in carp polyculture ponds did not significantly influence total production when compared to a carp only system. In one trial, total production increased in the treatments with mola from 4.2 to $4.4 \mathrm{t}$ per ha per seven months and, in another trial, total production was slightly lower in the treatments with mola, decreasing from 2.6 to $2.4 \mathrm{t}$ per ha per seven months (Table 1). Earlier, Rajts et al. (1997) recorded high mola production in a pond with a mix of other SIS, including bata (Labeo bata) and bhagna (Chirrhinus reba), at $0.8 \mathrm{t}$ per ha per seven months. Of studies that stocked SIS other than mola, chela was relatively less productive compared to mola, with production of just $0.1 \mathrm{t}$ per ha per seven months (Roy et al. 2002). Overall, pond production was also significantly lower $(2.2 \mathrm{t}$ per ha per seven months) in the presence of chela compared to the control system without SIS (2.6 $\mathrm{t}$ per ha per seven months), whereas carp-mola systems yielded $2.4 \mathrm{t}$ per ha per seven months which was not significantly different from the control system (Roy et al. 2002). There was no clear attribution as to why systems with chela were less productive than the control system, whereas systems with mola did not differ significantly from the control system (Roy et al. 2002). One of the higher SIS production levels of the studies reviewed, at $0.4 \mathrm{t}$ per ha per seven months, occurred in a study in which ponds poisoned with rotenone and subsequently stocked with large fish and mola were compared with ponds which were not poisoned, the natural communities of SIS remained and the ponds were subsequently stocked with large fish and mola (Roos et al. 2002b). There was a trend for higher total SIS production in the latter, underlying the value of the essential work done to stop traditional pond 'cleaning' practices such as continual netting or rotenone poisoning to kill all SIS before ponds were stocked.

Productivity was influenced by managerial, regional and physical factors, including species combination and stocking densities, pond water temperature and pond size. By manipulating the combination of species in the pond and removing one of the typical species of carp cultured, silver carp, it was possible to increase mola production from 0.1 to $0.3 \mathrm{t}$ per ha per seven months (Kadir et al. 2006; Kunda et al. 2009), though silver carp did not negatively affect mola production in all studies (Kunda et al. 2010; Wahab et al. 2011). Manipulating the species combination to include species that occupy different niches within the pond had no effect on SIS production but did influence overall pond productivity, particularly with inclusion of species such as common carp which stir up sediments and release nutrients back into the water column (Milstein et al. 2009; Wahab et al. 2011). Feed conversion ratios (FCRs) can be reduced by $20 \%$ under optimal species combinations and may be as low as 0.4-1.3 (Wahab et al. 2003, 2011). Regional differences in total productivity included $16 \%$ higher production in Mymensingh than in Bogra, Comilla or Magura, possibly attributed to warmer water temperatures in Mymensingh (Wahab et al. 2011). Rajts et al. (1997) and Roos et al. (2007b) suggest that the key to achieving high mola productivity is frequent, (i.e., bi-weekly) harvesting to sustain a healthy brood stock and avoid over-population. The evidence to date on carp-SIS productivity is piece-meal and comprehensive studies on optimal proportions of SIS and large fish as well as strategies for regular harvesting of SIS would enhance the benefits from carp-SIS polyculture systems.

\section{Income}

The income derived from the sale of fish from homestead pond carp-SIS polyculture systems was estimated to range from USD 878 to 3939 per ha per seven months, although it was not specified if this upper estimate was gross or net income (Table 1). Including a combination of large filter feeding species (fish which feed by straining suspended particles from the water column) such as catla, rohu and silver carp and bottom feeding species such as common carp and mrigal (which occupy different niches within the pond), led to a 


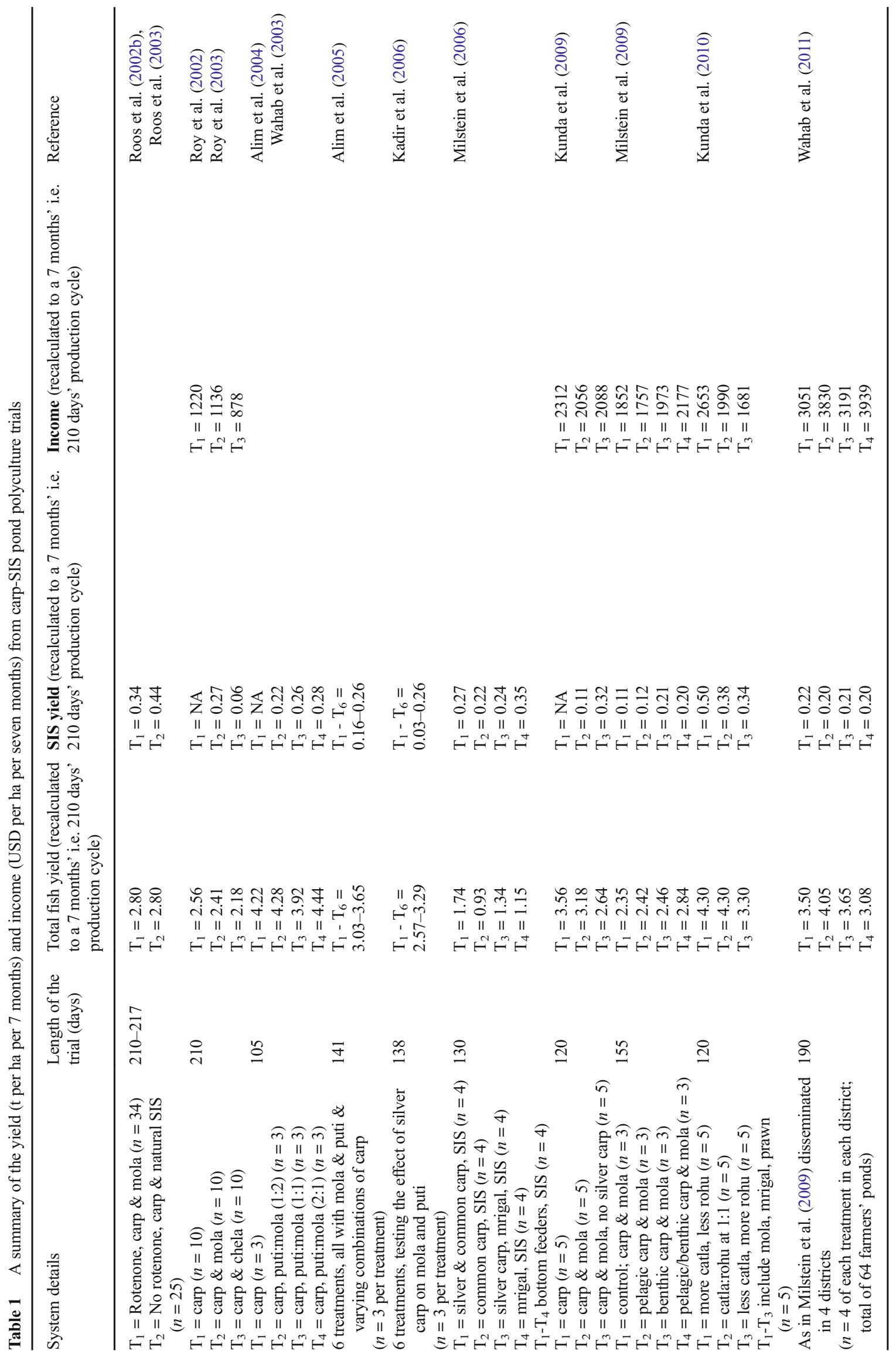


$30 \%$ increase in income, related to increased productivity and reduced FCR (Wahab et al. 2011). Carp-mola systems were more profitable than carp-chela systems; USD 1136 and USD 878 per ha per seven months, respectively (Roy et al. 2003). There was a trend for higher income from ponds without SIS compared to ponds with SIS (Table 1), because SIS brood stock (individuals used for breeding) is relatively expensive, if purchased, and this increases input costs in the first year of stocking SIS (Roy et al. 2003). It is likely that in perennial ponds, mola would survive from year to year, ensuring input costs would be reduced in subsequent years. Mola is also indigenous and for most farmers, could be collected from nearby waterways, reducing input costs for brood stock altogether. In addition, given that almost half of the mola cultured are consumed within the household (Roos et al. 2003, 2007b), a large portion of the SIS cultured are likely not to be given a monetary value in the calculation of household income generated from carp-SIS ponds, undervaluing the food production system and ignoring the fact that culturing SIS may reduce food expenditure. The above review demonstrates a lack of synthesized, quality evidence regarding the economic impact of adopting the carp-SIS production technology.

\section{Nutrition}

Fish consumption in households practising carp-SIS polyculture systems was reported in two studies; Roos et al. (2003) and Ahmmed et al. (2008). Roos et al. (2003) demonstrated that $47 \%$ of all mola produced in ponds were consumed by the household and that this equated to $4.2 \mathrm{~g}$ raw, edible parts of mola per person per day. This contributed $21 \%$ and $5 \%$ of the nutrient contribution ratio (NCR, the nutrient contribution from a food item as a percentage of the calculated household daily nutrient recommendation) for vitamin A and calcium, respectively (Roos et al. 2003). Ahmmed et al. (2008) showed slightly higher consumption of mola in households culturing mola compared to non-mola producing households. Furthermore, because SIS require frequent partial harvesting, some evidence suggests that this encouraged regular household consumption of small fish over sale in contrast to large fish which are harvested at the end of the season and the majority are sold (Milstein et al. 2009; Roos et al. 2002b). Ahmmed et al. (2008) demonstrated that consumption of SIS is typically much higher in geographic areas close to inland capture fisheries, where people consumed 48.5-50.4 g per capita per d of SIS compared to 5.9-7.1 g per capita per $\mathrm{d}$, in other areas. This indicates that inclusion of mola and other SIS in polyculture systems in areas without access to inland capture fisheries may be an important strategy to increase the quantity and diversity of SIS consumption.

No studies have evaluated the links between pond polyculture systems and nutritional outcomes such as anthropometry and biochemical markers, at an individual or household level. This is not surprising, in context of the broader literature gap on the impact of agricultural interventions on nutrition (Masset et al. 2012). Given the significant and well-recognised scope for food systems interventions, including fish production systems, to improve nutrition and health, this is an important gap that must be addressed.

Most of these data were generated in short-term trials. It was assumed that ponds are functional for seven months of the year and therefore the results were calculated for a 7 months' production period, for standardization purposes; using 210 days in 7 months. Consumption data were not included in this table because very few data were reported in the literature.

\section{Case studies}

\section{Methods}

\section{Projects}

We analyzed data from three major projects, which disseminated SIS production in existing homestead carp polyculture ponds in seven regions across Bangladesh (Fig. 1). These projects were: Project 1 "Small Fish and Nutrition", funded by the International Fund for Agricultural Development (IFAD; red dots on Fig. 1); Project 2 the "Cereal Systems Initiative for South Asia" (CSISA; green stars on Fig. 1), funded by USAID Feed The Future (FTF); and Project 3 the "Aquaculture for Income and Nutrition" (AIN) project, also funded by USAID FTF (yellow triangles on Fig. 1). These three projects were implemented by WorldFish and partner organizations.

The projects used similar criteria to select farmers. These criteria were that farmers demonstrated a genuine interest in carp-SIS polyculture production, that they were poor, with limited productive assets (generally $<1.2$ ha, used as an indicator of wealth) and that they have a homestead pond. All three projects had a strong focus on engaging women. However, each project used a different approach to engage with communities, facilitate learning and disseminate production technologies (Table 2).

Project 1: Small fish and nutrition This project focused on disseminating the carp-mola polyculture technology to households with stand-alone ponds and a small number of households with ponds connected to rice fields, as part of an integrated system with vegetable production, particularly vitamin A-rich orange sweet potato in homestead gardens and on pond dykes. The intervention took place in selected households, in two districts in northern Bangladesh (Fig. 1), beginning in 2011. This project was unique in that WorldFish partnered with the non-governmental organization Helen Keller International (HKI) to develop and implement a nutrition 


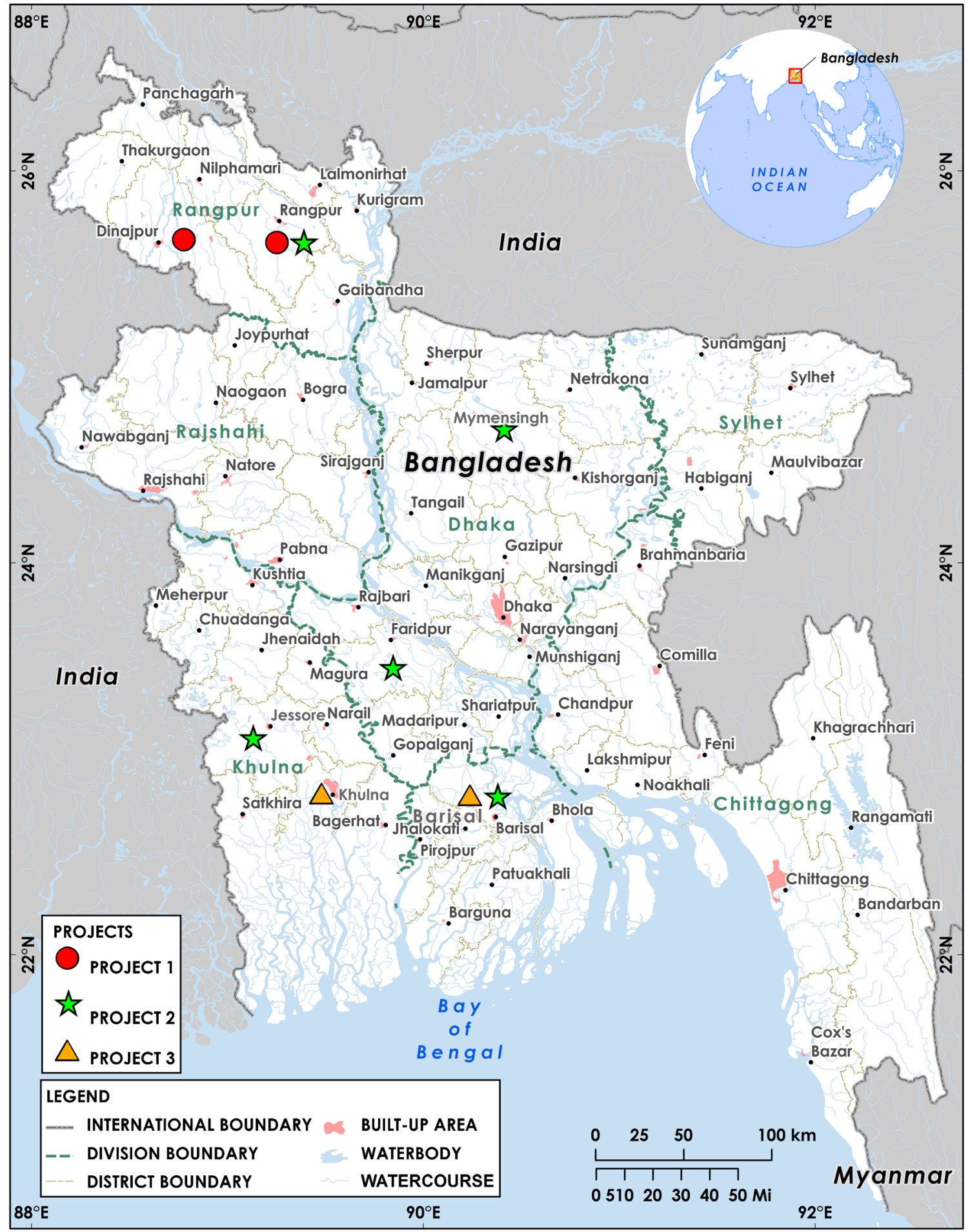

Source: VMAPO, GADMv2, Natural Earth

Fig. 1 Location of the three projects that disseminated homestead carp-SIS polyculture technologies

education and behavior change component. The project promoted increased consumption of micronutrient-rich small fish, vegetables and fruit, particularly in the first 1000 days of life and improved knowledge and practice of essential nutrition and essential hygiene actions, including practical training in food preparation, learnt through practical cooking classes. Given the importance of nutrition during the first 1000 days of life, households having a pregnant or lactating woman and infants and young children were selected. Gender norms and attitudes in relation to food purchase, intra-household food distribution and work load were also addressed. 


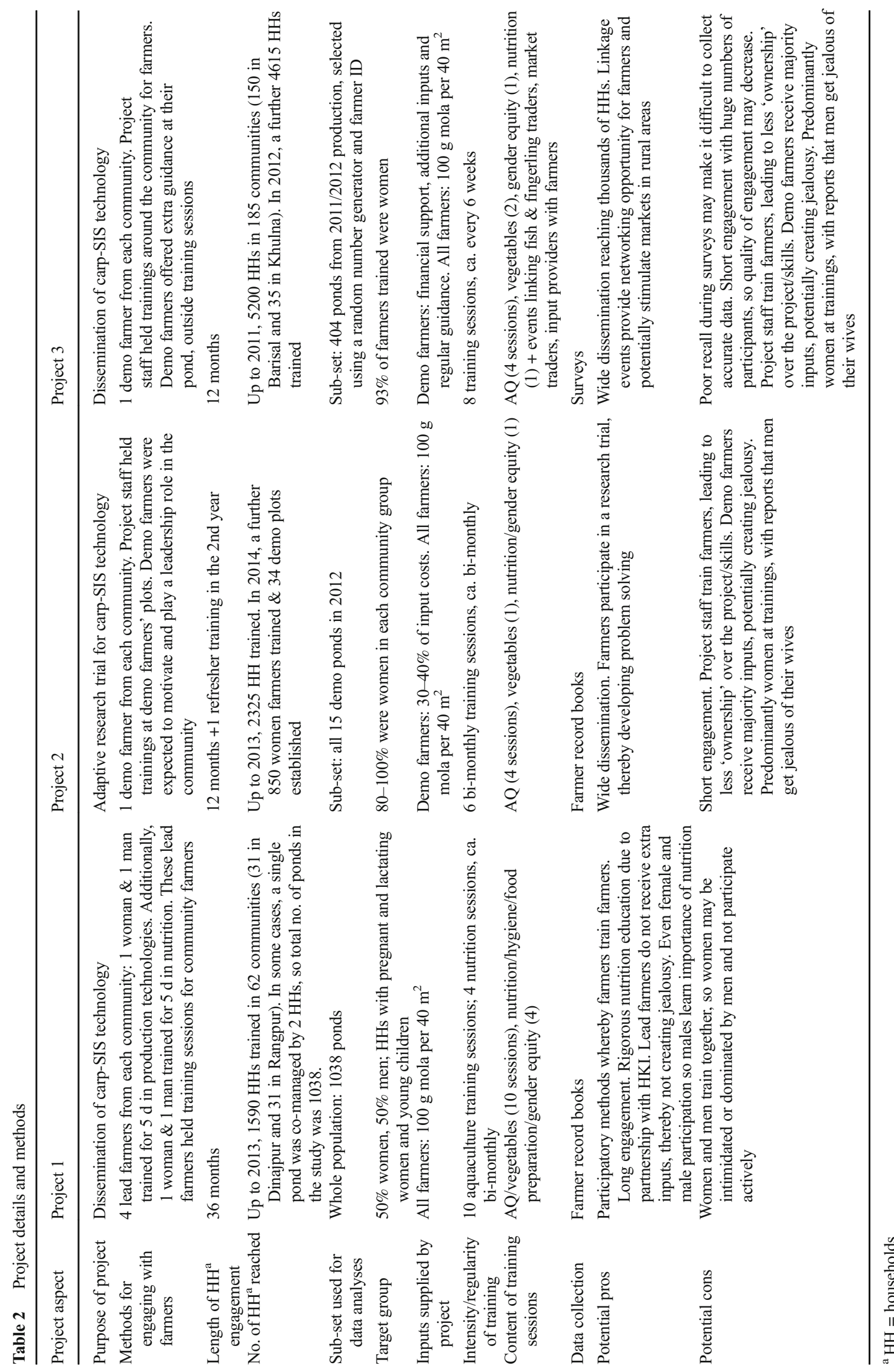


Four lead farmers, two women and two men, were selected by community members to conduct participatory training sessions. One woman and one man lead farmer attended a five days' training workshop on the technical aspects of carp-mola production; the two others attended a five days' training workshop on nutrition. Lead farmers received the equivalent of USD 1.30 per day to compensate for the time spent training. Lead farmers subsequently conducted training for community groups of 20-25 households, through ten technical sessions and four nutrition education sessions for each community. The only inputs given were $100 \mathrm{~g}$ mola brood stock per $40 \mathrm{~m}^{2}$ to all farmers (lead farmers and participating farmers). For monitoring purposes, every farmer kept a record book to record pond preparation, stocking, feeding, harvest and utilization of fish (sale, consumption and gifting).

\section{Project 2: Adaptive research trial in polyculture ponds} Project 2 was an adaptive research trial conducted in five districts (Fig. 1); three households in each district were selected to participate. The project differed from projects 1 and 3 in that it focused on technical feasibility aspects, for example, the use of low-cost feed ingredients and different techniques for pond sludge management. Project 2 comprised three training components; 1) technical training on carp-mola production, 2) technical training on vegetable production, and 3) messaging on nutrition and gender awareness. No practical training on food preparation was provided. The intervention targeted women farmers and $93 \%$ of participants were female.

Engagement with the community occurred in bimonthly demonstrations held at the ponds of 'demonstration farmers'. These were led by project staff with the aim of encouraging interaction between demonstration farmers, participating farmers and project staff to overcome problems and optimize management practices. Demonstration farmers received approximately $30-40 \%$ of the input costs from CSISA and were expected to actively participate in and contribute throughout the production cycle in order to play a leadership role in motivating the community. The invited farmers received $150 \mathrm{~g}$ mola brood stock per $40 \mathrm{~m}^{2}$ to stock in their ponds and purchased all other inputs, including large fish fingerlings. For monitoring purposes, every farmer kept a record book to record stocking, feeding, and production.

Project 3: Homestead pond polyculture for income and nutrition Project 3 was similar to project 1 in that it focused on dissemination of the carp-SIS technology, predominantly to women farmers. The project was wide-reaching, with almost 10,000 households trained over the duration of the project throughout the southern coastal zone of Bangladesh (Table 2, Fig. 1). Farmers were trained in groups of about 25 members and field staff conducted eight training sessions, approximately one training session every three weeks, lasting two hours each. Half of the training sessions focused on fish culture, two sessions were on vegetable production, one session on gender equity and one on nutrition. There were no structured cooking demonstrations.

Participatory research approaches were used to collect data from a sub-set (404) of farmers to evaluate the production technology and the potential to scale this technology to surrounding communities. Semi-structured interviews with the household's head female and male were conducted by project field staff. A baseline interview was conducted with every farmer, prior to participating in on-farm training, followed by a mid-point interview and an end-point interview, all with a sub-set of farmers.

\section{Data analyses}

We analyzed data relating to productivity (t per ha per season), income (USD per ha per season, with examples of USD per pond per season), food and nutrition security (fish consumption in $\mathrm{kg}$ per household per season, total macro- and micronutrient production per pond per season) and gendered workload (time spent in minutes per day by women and men on different tasks pertaining to homestead pond culture).

We first explored and plotted the production data to assess the distribution, homogeneity and degree of confounding using 'lattice' graphics, available from the R statistical software package (Sarkar 2008). Production data were complex, being collected from six different districts, seasonal and perennial ponds, isolated ponds, a small number of ponds connected to rice fields, and from single household owned ponds and share ponds. For the purpose of this study, we aggregated across dimensions within each project and analyzed only data at the level (dimension) of different projects. The average seasonal yields of three categories of fish were calculated; 1) large fish, 2) mola and 3) other SIS, and the results are presented in section 3.2.1.

The income data generated from selling carp and small fish under Project 1 were collected over two seasons, whereas, income data from Projects 2 and 3 were generated over one season. Net income was calculated for farmers participating in Projects 1 and 3, with fixed costs (rent of land, cost of equipment) and variable costs (seed, feed and fertilizer inputs) deducted from the gross revenue from selling fish. For Project 2, fixed costs were not recorded and a large portion of the inputs were provided by the project. In this case, we calculated income by deducting the variable costs (seed, feed and fertilizer inputs) from the gross revenue.

Species production data from Project 2 were used to investigate the potential contribution of a homestead pond to household food and nutrition security, by calculating nutrients produced by each species per production cycle. Firstly, the mean yield of each species per homestead pond per production cycle (season) was calculated. This was then converted to 'raw, edible parts' production, or the amount of fish produced that is edible (excluding non-edible parts such as viscera and bones 
in some species), using an edible portion coefficient (EPC) for large and small fish (Roos 2001). Thus, the values calculated represent the amount of fish produced that actually contributed to nutrient intake, and not just total production, measured as raw weight of fish. Nutrient composition for each species was then used to calculate nutrient production from each species, from each pond per season. Nutrients of interest considered here are those of public health significance in Bangladesh, particularly during the first 1000 days of life; minerals and vitamins: iron, zinc, calcium, vitamin B12 and vitamin $\mathrm{A}$, as well as macronutrients: protein and fat (Craviari et al. 2008; ICDDRB et al. 2013).

We also explored the distribution of labor inputs between women and men and the time spent on different tasks relating to homestead pond production, using data from Projects 2 and 3 . These data were explored visually initially and one outlier was removed because it was not logical.

\section{Results}

\section{Production}

Farmers across the three projects produced between 1.3 and $5.1 \mathrm{t}$ large fish per ha per season and between 0.2 and $0.6 \mathrm{t}$ mola per ha per season (Fig. 2). Yields reported here are in line with those found in the literature review of on-farm and controlled trials (Table 1). Given that average pond size in Bangladesh is 0.1 ha, this equates to $130-510 \mathrm{~kg}$ large fish per pond per season and $20-60 \mathrm{~kg}$ mola per pond per season. Farmers participating in Project 2, the adaptive research trial with fewer participants and more inputs given to demonstration farmers, achieved the highest production (Fig. 2). Under Project 2, except mola, there were no other small fish in the 'other SIS' category, as all other naturally recruiting SIS were removed from the pond before stocking (Fig. 2). This potentially decreased competition for mola as demonstrated by the high mola production but it also dramatically reduced production diversity and thus the diversity

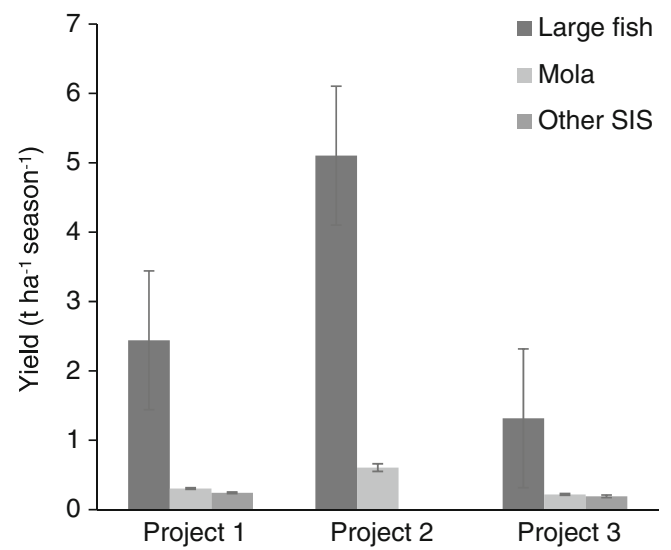

Fig. 2 The mean \pm standard error yield of large fish, mola and other SIS achieved by project farmers of fish species available for consumption. Production diversity was comprised of eight different stocked species: mola, catla, common carp, grass carp (Centopharygodon idella), kalibaus (Labeo calbasu), mrigal, silver carp, and tilapia (Oreochromis niloticus) and a variety of un-recorded, self-recruiting small fish species likely including, but not limited to, puti and darkina. The mean $( \pm \mathrm{SE})$ number of species cultured in a pond was relatively low; $5.3 \pm 1.3$ species per pond.

\section{Income}

The income data generated from selling carp and small fish under Project 1 were collected over two seasons (2011 and 2012). There was an increasing trend in income from year 1 (USD $1650 \pm 307$ ) to year 2 (USD $2769 \pm 363$ ). These increases could be attributed to climatic differences from one year to the next (2012 was particularly wet in the beginning of the season) and/or to improved production efficiencies as the project progressed. Farmers participating in Project 2 achieved a net income of USD $4456 \pm 426$ per ha per season, and at the household level, this amounted to an average of USD 161 per season. Project 3 farmers generated a net profit of USD $3296 \pm 178$ per ha per season from large fish and USD $517 \pm 32$ per ha per season from SIS.

\section{Fish consumption and nutrition}

In Project 1, in which there was a strong partnership with HKI in promoting nutrition, households consumed more SIS and large fish than participants in the other projects (Table 3), despite achieving only moderate yields (Fig. 2). Households in Project 1 consumed a total of $13.1 \mathrm{~kg}$ mola and other SIS per household per season, compared to Projects 2 and 3; 12.3 and $6.7 \mathrm{~kg}$ mola and other SIS per household per season, respectively (deduced from Table 3). The diversity of small fish species consumed in Project 1 was also larger, with a strong focus on consuming 'other SIS' as well as mola (Table 3).

Regarding the nutritional quality of the fish consumed, small fish make up a relatively small contribution of total production and consumption by weight: however, they contribute a major proportion of the micronutrients produced in the pond system. The nutrients produced in homestead pond polyculture system in Project 3 are shown in Table 4,

Table 3 The mean \pm standard error consumption of fish ( $\mathrm{kg}$ per household per season) in Projects 1-3 in 2012

\begin{tabular}{lllll}
\hline Project & Large fish & Mola & Other SIS $^{\mathrm{a}}$ & Total \\
\hline Project 1 & $59.8 \pm 3.4$ & $4.7 \pm 0.6$ & $8.4 \pm 0.6$ & 72.9 \\
Project 2 & $45.0 \pm 6.2$ & $12.3 \pm 1.1$ & $0.0 \pm 0.0$ & 57.3 \\
Project 3 & $27.6 \pm 1.3$ & $6.7 \pm 0.3$ & $0.0 \pm 0.0$ & 34.3 \\
\hline
\end{tabular}

${ }^{\mathrm{a}} \mathrm{SIS}=$ small indigenous fish species 
including their proportional contribution to production of each nutrient. Of note, mola contributed $98 \%$ of total vitamin A produced, $56 \%$ of total iron, $46 \%$ of total vitamin B12, $35 \%$ of total zinc, and $30 \%$ of total calcium, despite accounting for only $15 \%$ of total fish production by weight (Table 4). This is in stark contrast to large fish species which accounted for $85 \%$ of total production by weight, but for only $1 \%$ of total vitamin A produced. The contributions to protein production largely align with contributions to total fish production, regardless of whether the fish is a large or small species.

The raw, edible parts of fish are larger for small fish than for large fish because there is significant weight in bones, viscera and other body parts that, in large fish, are discarded as plate waste. For example, total fresh weight production of mola is adjusted with a weight loss of $12 \%$ for non-edible parts, whereas, for silver carp, the weight loss is $17 \%$ (Table 4). This has implications for the nutrient contribution from edible parts of fish of different species.

\section{Gendered work load}

The labor required to maintain a homestead polyculture system can determine the feasibility and longevity of the system. We analysed data from Projects 2 and 3 to determine the labor inputs to a polyculture pond. Under Project 3, a family spends an average of just over half an hour per day working on the homestead pond over the course of a year. All ponds under Project 3 were perennial ponds, so they were functional for almost 365 days. Feeding was by far the most time-consuming single activity, requiring approximately $13 \mathrm{~min}$ a day. On average, women did $55 \%$ of the feeding. Women also contributed $72 \%$ of the labor for miscellaneous tasks pertaining to the homestead ponds, which required approximately 14 min per day. In $3 \%$ of the harvesting events of mola, women harvested mola without men. This is compared to $52 \%$ of the harvesting events in which men harvested mola without women and $45 \%$ of the events in which women and men harvested mola together. Cast nets, of varying size and weight, were used $83 \%$ of the time.

Women contributed half of the labor for pond preparation, stocking, fertilization, and weeding. By these estimates, women spent between $15 \mathrm{~min}$ and half an hour per day working on the homestead pond.

Similarly, under Project 2, women spent an average of $21 \mathrm{~min}$ per day working on the pond during the culture period. The time spent working ranged from zero to $98 \mathrm{~min}$ per day and this large range likely reflected the variability in work load, depending on the stage of the production cycle, with stocking and harvesting being the most labor-intensive times. Men spent slightly longer on average, 25 min per day, with a range from zero to $114 \mathrm{~min}$ per day.

These data, collected from farmer record books and surveys, are a useful indication of the division of labor and time required to manage a pond. A quality monitoring and evaluation framework is recommended to quantify the time required by women and men to culture carp-SIS and to determine the impact on other household tasks, such as caring for children.

\section{Discussion}

This paper demonstrates that for farmers with suitable resources, the carp-SIS pond polyculture technology is productive and has the potential to improve household food and nutrition security. Approximately $20 \%$ of all rural households (4.27 million households) own multifunctional homestead ponds, and in recent decades, there has been significant investment in improving the production of large fish species in these systems (Belton and Azad 2012; Belton and Little 2011; Belton et al. 2011). Together with evidence from Bogard et al. (2015) and Roos (2001), there is a strong case for promoting production systems that combine large fish and SIS to significantly improve access to micronutrients for poor rural households.

\section{Fish for food and nutrition}

In this paper we quantified, for the first time, the total production of macro- and micronutrients from homestead ponds. This is an important first step towards investigating the potential impact of carp-SIS culture on nutrient intake of poor households. Results from Project 3 demonstrated that despite only accounting for $15 \%$ of production by weight, mola produced $98 \%, 56 \%$, and $35 \%$ of the vitamin A, iron and zinc, respectively, in the pond system. If all mola produced is consumed within the household, this would contribute to $54 \%$ of vitamin A, $42 \%$ of vitamin B12, $26 \%$ of calcium, and $24 \%$ of iron needs for a family of four (a lactating woman, an adult male, a child $<2$ years, and a child of 9 years of age), for one year (FAO and WHO 2004). This demonstrates the important direct contribution of SIS to nutritional quality of diets, and the complementary role that carp-SIS polyculture systems can play in contributing to household nutrition.

Linking agricultural interventions to changes in dietary patterns or improvements in nutritional status during short-term projects is particularly difficult and the present study has limitations (Masset et al. 2012; Webb 2013). While results reported here are useful indications of the potential nutritional impacts of improved homestead fish production, they cannot replace measures of dietary diversity, diet quality, food safety, sanitation and the status of women which all underpin the nutritional outcomes of a nutrition-sensitive agricultural project (CGIAR ISPC 2014). To elicit sustainable behavioral changes in consumption and nutritional status, a project should not only engage with communities for the duration of the project but should establish on-going, multi-sectorial support across agricultural extension networks, the health sector, early childhood development and schooling. Coordination 


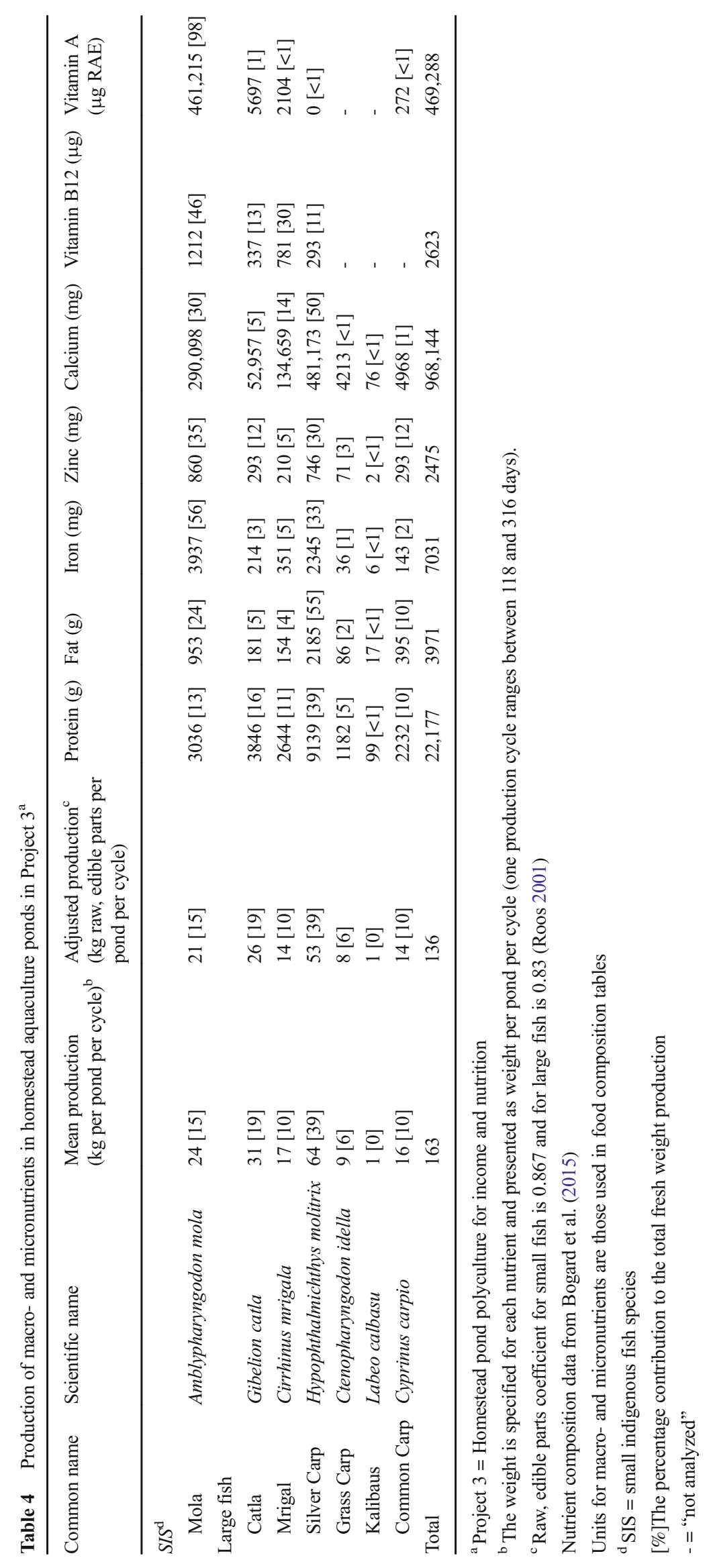


across sectors requires joint planning, implementation and monitoring, as well as policies that are conducive to broader change across sectors and along market value chains (Ruel et al. 2013; Thilsted et al. 2016).

Finally, in addressing the limitations of the projects, we acknowledge that the production and consumption data presented here were collected through farmer record books and surveys and there was no independent monitoring and evaluation. This potentially may compromise the quality of the data. Further research should include an independent monitoring and evaluation system to record production at species level, nutritional status of all household members and intra-household food consumption. Monitoring consumption at the individual level is particularly important because food distribution, particularly of animal-source foods, is often uneven, with women and girls typically eating less than men and boys (Chen et al. 1981; Hossain 2004; Razzaque et al. 2011; Roos 2001).

\section{Production, income and labor}

Farmers in the projects produced between 1.5 and $5.5 \mathrm{t}$ fish per ha per season which is equal to or above the national average of approximately $1.5 \mathrm{t}$ fish per ha per season in homestead ponds (Belton and Azad 2012; Jahan et al. 2010) and is within the ranges reported in the literature review in Table 1. These data demonstrate that by integrating SIS into carp polyculture ponds and participation of farmers, both women and men, in aquaculture and nutrition training, there is opportunity to improve production and maximize nutritional benefits from homestead ponds. Training and extension projects for carp polyculture in homestead ponds have proved effective in the past, achieving yield improvements of $23 \%$ per annum (Jahan et al. 2010; Jahan et al. 2008), and it is likely that similar gains could be achieved for projects focusing on carp-SIS production in homestead ponds and even larger production ( $7.4 \mathrm{t}$ fish per ha per year) in ponds connected to rice fields (Thilsted and Wahab 2014b).

Despite the productivity improvements in isolated homestead ponds and ponds connected to rice fields, the upfront financial investment required may limit adoption of this technology by some households. This is especially the case when considering that a family spends an average of half an hour per day working on the pond and it may provide as little as $2.8 \%$ of the total household income (Belton and Azad 2012; Jahan et al. 2008). However, there are indirect financial gains from homestead aquaculture relating to food expenditure, particularly in efficiently managed systems (Kumar and Quisumbing 2010). It is likely that consumption expenditure on fish would reduce in households practising carp-SIS polyculture, freeing up income for other necessities as it does for carp polyculture (Belton 2013). There is anecdotal evidence that the increased awareness of the nutritional benefits of SIS has increased the price of SIS in some areas, potentially reducing access of this important animal-source food to poor consumers. In this regard, homestead production of small fish could be a crucial and cost effective way of enabling access of nutritious SIS to poor consumers, especially women and young children. Furthermore, aquaculture production of SIS might help to reign in prices as it has done for large fish species (Belton and Thilsted 2014). In addition, the regular and continual harvesting of small amounts of fish for the majority of the year alleviates periods of low or variable income related to seasonality in other agricultural crops such as rice (Belton 2013; Belton et al. 2014). Integrating vegetable production, such as orange fleshed sweet potato on pond dykes, also has the potential to boost household income and reduce consumption expenditure (Thilsted and Wahab 2014d). A detailed cost-benefit analysis conducted at the household level and reported in relation to total household income is essential for evaluating the financial gains and real impact that adopting the carp-SIS technology could have on a household's income and food expenditure.

In this paper, we report, for the first time, on the duration (an average of 15-20 min per day) that women spend participating in homestead carp-SIS aquaculture and that women's participation is primarily at the husbandry stages. This is a relatively large contribution, considering the heavy work load that women have around the home. However, this may have huge potential benefits if women control the income from carp-SIS ponds. A small gender study in Project 2 described select cases with women having control over the income earned from carp-SIS pond polyculture but that this was not the case for all women (Morgan et al. 2014). One benefit of women controlling the income is that they typically use the money for food, health care and education of their children (Smith et al. 2003). An analysis of the dynamics and power relations between women and men with regard to work load and income earned from carp-SIS polyculture is needed to gauge how this technology impacts women's status within the household and in the community.

\section{Scaling carp-SIS polyculture: Lessons learned}

Investment from the public and private sectors is now needed if significant gains for income and nutrition are to be attained from carp-SIS production. This will require a shift away from scaling efforts being driven by isolated development (interventionist) projects, towards being driven by government and the private sector. Along these lines, recent policy briefs recommend that the Ministries of Fisheries and Livestock, Health and Family Welfare, Food and Disaster Management, and Education take measures to provide financial support and training to extension networks, support research at national institutions and universities and ensure this technology is included in forthcoming policies and strategies (Thilsted and Wahab 2014a and c). This process has already started with pockets of work emerging through the 
Department of Fisheries (DoF). Four abstracts were presented at a fisheries research conference in Dhaka by DoF staff (Habib et al. 2014; Hoque et al. 2014; Mondal et al. 2014; Saha et al. 2014), and DoF was directly engaged in the implementation and training in Project 1 , resulting in carp-SIS production technology being added to the portfolio of technologies taught to extension agents and promoted by DoF staff (pers. comm. B. Barman).

Strong partnerships are instrumental in the successful dissemination of the carp-SIS technology. Partnering with DoF helped to increase awareness of the benefits of small fish and the capabilities and benefits of women in managing homestead ponds. The projects described in this paper critically begin to address the gender gap in access to agricultural extension services, knowledge and training, which are consistently lower for women than for men (Ragasa et al. 2013). In taking a comprehensive household approach and engaging both women and men, as in Project 1, men also critically learn the value of access and equitable intake of nutritious food amongst all household members. This model also provides a platform to address gender inequity in access to and control of productive assets, as both women and men are present in training sessions. Conversely, in Projects 2 and 3, women typically participated in training alone, allowing more space for learning by women and full responsibility for their pond and the income.

\section{Conclusion}

This study has reviewed the evidence on homestead pond polyculture systems in Bangladesh and has shown that such systems can be successfully managed to produce large fish and a variety of SIS, including mola. Furthermore, systems with large fish and SIS produce more micronutrients than homestead ponds managed under traditional carp (large fish) polyculture regimes and are therefore uniquely placed to contribute to improved nutrition. Two key conclusions regarding an effective approach for disseminating the carp-SIS technology were also apparent from this study. Firstly, taking a household approach for training on technical aspects of carp-SIS production as well as for nutrition training has the potential to empower women in decisionmaking regarding household fish consumption and may make micronutrients more accessible to vulnerable members within the household. Secondly, the dissemination process could be strengthened by partnering with other sectors, including the nutrition and health sector, the private sector and government agencies. Partnering with the nutrition and health sector is essential to building the capacity of those delivering the production technology, to ensure women are included in homestead food production and to maximise the nutritional impacts, particularly during the first 1000 days of life.

The nutrition and health impacts of shifting from carp polyculture to carp-SIS polyculture for farming households have not been elucidated. Quantifying fish consumption (at species level) of individual household members and measuring changes in diet quality are therefore essential to determine the impact of efforts to scale and disseminate the carp-SIS production technology. Investment in comprehensive research around the production techniques and nutritional impacts of other species of SIS (besides mola), and the power dynamics between women and men in operating homestead ponds should be prioritized in order to maximize potential gains.

Acknowledgements The work reported in this paper was partially funded by the International Fund for Agricultural Development (IFAD), through the "Small Fish and Nutrition" project; as well as the U.S. Agency for International Development (USAID) Feed the Future (FTF) initiative, through the "Cereal Systems Initiative for South Asia (CSISA) project" and the "Aquaculture for Income and Nutrition (AIN)" project, implemented by WorldFish, in Bangladesh. The contents and opinions expressed herein are those of the authors and do not necessarily reflect the views of IFAD or USAID or the United States Government. This work is a contribution to the CGIAR Research Program (CRP) on Aquatic Agricultural Systems (AAS). We would like to acknowledge Mr. Md. Hadayet Ullah, Dr. Rayhan Hayat Sarwer, and Ms. Susmita Choudhury for assistance with data collection, cleaning and preliminary analyses and Mr. Jason Benedict, ERE Consulting Group, Malaysia for assistance with Fig. 1. We would also like to thank Dr. John Benzie for support with writing the paper.

\section{Compliance with ethical standards}

Conflict of interest The authors declared that they have no conflict of interest

\section{References}

Ahmmed, A. U., Nahiduzzaman, M., Sayeed, M. A., Akter, M., \& Hossain, M. A. R. (2008). Consumption pattern of small indigenous species (SIS) of fish with special emphais on mola. (Amblypharyngodon Mola) amoung growers and non-growers level. J. Agrofor. Environ., 2, 167-170.

Alim, M. A., Wahab, M. A., \& Milstein, A. (2004). Effects of adding different proportions of the small fish punti (Puntius sophore) and mola (Amblypharyngodon mola) to a polyculture of large carp. Aquaculture Research, 35, 124-133.

Alim, M. A., Wahab, M. A., \& Milstein, A. (2005). Effects of increasing the stocking density of large carp by $20 \%$ on 'cash' carp-small fish polyculture of Bangladesh. Aquaculture Research, 36, 317-325.

Ameen, M., Islam, K. R., Ahmed, K., \& Mostafa, G. (1984). Indigenous small fish culture in mini-ponds. Bangladesh Journal of Zoology, 12, $1-10$.

Azadi, M. A., \& Mamun, A. (2004). Reproductive biology of he cyprinid, Amblypharyngodon mola (Hamilton) from the Kaptai reservoir, Bangladesh. Pakistan Journal of Biological Sciences, 7, 1727-1729.

Belton, B. (2013). Small-scale aquaculture, development and poverty: a reassessment. in: Enhancing the contribution of small-scale aquaculture to food security, poverty alleviation and socio-economic development, (Eds.) M.G. Bondad-Reantaso, R.P. Subasinghe, FAO Fisheries and aquaculture proceedings no. 31., Rome, pp. 93-108.

Belton, B., \& Azad, A. (2012). The characteristics and status of pond aquaculture in Bangladesh. Aquaculture, 358-359, 196-204. 
Belton, B., \& Little, D. C. (2011). Immanent and interventionist inland Asian aquaculture development and its outcomes. Development policy review, 29, 459-484.

Belton, B., \& Thilsted, S. H. (2014). Fisheries in transition: Food and nutrition security implications for the global south. Global Food Security, 3, 59-66. doi:10.1016/j.gfs.2013.10.001.

Belton, B., Karim, M., Thilsted, S., Jahan, K. M., Collis, W., \& Phillips, M. (2011). Review of aquaculture and fish consumption in Bangladesh. In Studies and reviews 2011-53. The WorldFish: Center. http://pubs. iclarm.net/resource centre/WF 2970.pdf. Accessed 1 Dec 2012

Belton, B., van Asseldonk, I. J. M.̄, \& Thilsted, S. H. (2014). Faltering fisheries and ascendant aquaculture: Implications for food and nutrition security in Bangladesh. Food Policy, 44, 77-87. doi:10.1016/j.foodpol. 2013.11.003.

Bogard, J. R., Thilsted, S. H., Marks, G. C., Wahab, A., Hossain, M. A. R., Jakobsen, J., \& Stangoulis, J. (2015). Nutrient composition of important fish species in Bangladesh and potential contribution to recommended nutrient intakes. Journal of Food Composition and Analysis, 42, 120-133. doi:10.1016/j.jfca.2015.03.002.

CGIAR ISPC. (2014). Nutrition and health outcomes: Targets for agricultural research, Brief no. 43. Italy: Rome http://ispc.cgiar.org/ publication/nutrition-and-health-outcomes-targets-agriculturalresearch-brief-no-43. Accessed 25 Sep 2016.

Chen, L. C., Huq, E., \& D'Souza, S. (1981). Sex bias in the family allocation of food and health care in rural Bangladesh. Population and Development Review, 7(1), 55-70.

Craviari, T., Pettifor, J. M., Thacher, T. D., Meisner, C., Arnaud, J., Fischer, P. R., \& The Rickets Convergence Group. (2008). Rickets: An overview and Future directions, with special reference to Bangladesh. Journal Health Population and Nutrition, 26, 112-121.

Dewey, K. G., \& Vitta, B. S. (2013). Strategies for ensuring adequate nutrient intakes for infants and young children during the period of complementary feeding. In Alive \& Thrive. A\&T Technical Brief, 7. http://aliveandthrive.org/wp-content/uploads/2014/11/Insight-Issue7_Ensuring-Adequate-Nutrition.pdf. Accessed 14 Feb 2014

FAO \& WHO (2004). Vitamin and mineral requirements in human nutrition: Report of a joint FAO/WHO expert consultation. Bangkok, Thailand, 21-30 September 1998.

Felts, R. A., Rajits, F., \& Akteruzzaman, M. (1996). Small indigenous fish species culture in Bangladesh (Technical brief). IFADEP sub Project-2. Development of inland fisheries, $41 \mathrm{pp}$.

Gupta, S., \& Banerjee, S. (2013). Food and feeding habit of Amblypharyngodon mola (Hamilton-Buchanan, 1822) in West Bengal, India. International Journal of Scientific Research, 2, 67-71.

Habib, K. A., Ali, M. L., \& Hossain, M. A. R. (2014). Impact of mola, Amblypharyngodon mola, culture with carps in ponds and pond connected rice fields on biodiversity, production, consumption and income of associated non-associated households. In $6^{\text {th }}$ biennial fisheries conference and research fair 2014-04-24. Dhaka: Bangladesh.

Hoque, A. S. M. M., \& Rahman, M. R. (2008). Reproductive ecology of Mola (Amblypharyngodon mola). Journal of agriculture and rural development, 6, 165-174.

Hoque, M. M., Haque, S. M., Wahab, M. A., \& Motin, M. A. (2014). Water quality and plankton composition in mola (Amblypharyngodon mola) pond stocked at different density. In $\sigma^{\text {th }}$ biennial fisheries conference and research fair 2014. Dhaka: Bangladesh.

Hossain, M. A. (2004). Fish consumption in Bangladesh: A study on per capita fish consumption on the basis of gender, location and wealth class in relation to species, size and value. Mymensingh, Bangladesh: Bangladesh Agricultural University.

ICDDRB, UNICEF, GAIN, \& IPHN (2013). National micronutrients status survey 2011-12. https://static1.squarespace.com/static/ 56424f6ce4b0552eb7fdc4e8/t/57490d3159827e39bd4d2314/ 1464405328062/Bangladesh NMS final report 2011-12.pd. Accessed 10 March 2014
Jahan, K. M., Beveridge, M. C. M., \& Brooks, A. C. (2008). Impact of long-term training and extension support on small-scale carp polyculture farms of Bangladesh. Journal of the World Aquaculture Society, 39(4), 441-453.

Jahan, K. M., Ahmen, M., \& Belton, B. (2010). The impacts of aquaculture development on food security: Lessons from Bangladesh. Aquaculture Research, 41, 481-495.

Kadir, A., Kundu, R. S., Milstein, A., \& Wahab, M. A. (2006). Effects of silver carp and small indigenous species on pond ecology and carp polycultures in Bangladesh. Aquaculture, 261(3), 1065-1076.

Kohinoor, A. H. M., Wahab, M. A., Islam, M. L., \& Thilsted, S. H. (2001). Culture potentials of mola (Amblypharyngodon Mola), chela (Chela cachius) and punti (Puntius sophore) under monoculture system. Bangladesh Journal of Fisheries Research, 5, 123-134.

Kumar, N., \& Quisumbing, A. R. (2010). Access, adoption and diffusion. Understanding the long-term impacts of improved vegetable and fish technologies in Bangladesh. IFPRI discussion paper 00995. doi: $10.1080 / 19439342.2011 .570452$.

Kunda, M., Nahid, S. A. A., Wahab, M. A., \& Thilsted, S. H. (2009). Culture potential of Amblypharyngodon mola with carps in polyculture in farmer's ponds of northern regions of Bangladesh. Bangladesh Journal of Fisheries Research, 13, 1-10.

Kunda, M., Mahakur, B., Sengupta, G., Wahab, M. A., Roos, N., \& Thilsted, S. H. (2010). Introducing the nutrient dense, small indigenous fish species, mola (Amblypharyngodon mola) in pond aquaculture with carps and prawns in Sunderbans, India. Asia Pacific Journal of Rural Development, 20, 19-32.

Mamun, A., Tareq, K. M. A., \& Azadi, M. A. (2004). Food and feeding habits of Amblyaryngodon mola (Hamilton) from Kaptai reservoir, Bangladesh. Pakistan Journal of Biological Sciences, 7, 584-588.

Masset, E., Haddad, L., Cornelius, A., \& Isaza-Castro, J. (2012). Effectiveness of agricultural interventions that aim to improve nutritional status of children: systematic review. BMJ, 344. doi:10. 1136/bmj.d8222.

Michaelsen, K. F., Dewey, K. G., Perez-Exposito, A. B., Nurhasan, M., Lauritzen, L., \& Roos, N. (2011). Food sources and intake of n-6 and $n-3$ fatty acids in low-income countries with emphasis on infants, young children (6-24 months), and pregnant and lactating women. Maternal \& Child Nutrition, 7, 124-140.

Milstein, A., Ahmed, A. F., Masud, O. A., Kadir, A., \& Wahab, M. A. (2006). Effects of filter feeding silver carp and the bottom feeders mrigal and common carp on small indigenous fish species (SIS) and pond ecology. Aquaculture, 258, 439-451.

Milstein, A., Wahab, M. A., Kadir, A., Sagor, M. F. H., \& Islam, M. A. (2009). Effects of intervention in the water column and/or pond bottom through species composition on polycultures of large carps and small indigenous species. Aquaculture, 286(3-4), 246-253.

Mondal, S., Wahab, M. A., \& Barmon, B. K. (2014). Production and economic performance in three stocking and management regimes of carps and mola in north-West Bangladesh. In 6th biennial fisheries conference and research fair 2014. Dhaka: Bangladesh.

Morgan, M., Choudhury, A., Braun, M., Beare, D., Benedict, J. and Kantor, P. (2014). Understanding the gender dimensions of adopting climate-smart smallholder aquaculture innovations. Penang, Malaysia: CGIAR Research Program on Aquatic Agricultural Systems. Working Paper: AAS-2015-08. http://pubs.iclarm.net/ resource_centre/AAS-2015-08.pdf. Accessed 15 Nov 2015

Piska, R. S., \& Waghray, S. (1986). Some aspects of reproductive biology of A. mola (ham.) Geobios, 13, 204-207.

Ragasa, C., Berhane, G., Tadesse, F., \& Taffesse, A. S. (2013). Gender differences in access to extension services and agricultural productivity. Journal of agricultural education and extension, 19, 437-468.

Rajts, F., Ahmed, K. K., Khan, A. M., \& Kaiya, M. K. (1997). Pond management and controlled breeding of Amblypharyngodon mola - a small indigenous fish species in Bangladesh. In Proceedings of National Workshop on small indigenous fish culture in Bangladesh. 
Integrated food assisted development project SP-2 (IFADEP SP 2), Dhaka, Bangladesh, pp. 71-79.

Razzaque, M. A., Khondker, B. H., \& Raihan, S. (2011). Poverty, intrahousehold distribution and gender relations in Bangladesh: Evidence and policy implications. Dhaka: University Press Limited.

Roos, N. (2001). Fish consumption and aquaculture in rural Bangladesh: nutritional contribution and production potential of culturing small indigenous fish species (SIS) in pond polyculture with commonly cultured carps. Ph.D. thesis, Royal Veterinary and Argicultural University, Reserach department of Human Nutrition, Copenhagen.

Roos, N., Leth, T., Jakobsen, J., \& Thilsted, S. H. (2002a). High vitamin a content in some small indigenous fish species in Bangladesh: Perspectives for food-based strategies to reduce vitamin a deficiency. International Journal of Food Sciences and Nutrition, 53, 425-437.

Roos, N., Thilsted, S. H., \& Wahab, M. A. (2002b). Culture of small indigenous fish species in seasonal ponds in Bangladesh: The potential for production and impact on food and nutrition security, In: Rural Aquaculture, (Eds.) P. Edwards, D. Little, H. Demaine: CABI Publishing, Wallingford.

Roos, N., Islam, M. M., \& Thilsted, S. H. (2003). Small fish is an improtant dietary source of vitamin a and calcuim in rural Bangladesh. International Journal of Food Sciences and Nutrition, 54(5), 329-339.

Roos, N., Wahab, M. A., Chamnan, C., \& Thilsted, S. H. (2007a). The role of fish in food-based strategies to combat vitamin a and mineral deficiencies in developing countries. The Journal of Nutrition, 137, 1106-1109.

Roos, N., Wahab, M. A., Hossain, M. A. R., \& Thilsted, S. H. (2007b). Linking human nutrition and fisheries: Incorporating micronutrientdense, small indigenous fish species in carp polyculture production in Bangladesh. Food and Nutrition Bulletin, 28(2), S280-S293.

Roy, N. C., Kohinoor, A. H. M., Wahab, M. A., \& Thilsted, S. H. (2002). Evaluation of performance of carp-SIS polyculture technology in the rural farmer's ponds. Asian Fisheries Science, 15, 43-52.

Roy, N. C., Wahab, M. A., Khatoon, H., \& Thilsted, S. H. (2003). Economics of carp-SIS polyculture in rural farmer's pond. Pakistan Journal of Biological Sciences, 6, 61-64.

Ruel, M., Alderman, H., \& Maternal and Child Nutrition Study Group (2013). Nutrition-sensitive interventions and programmes: how can they help to accelerate progress in improving maternal and child nutrition? The Lancet. http://www.sciencedirect.com/science/ article/pii/S0140673613608430. Accessed 5 May 2014.

Saha, M. K., Hossain, M. A. R., \& Barmon, B. K. (2014). Morphometry, breeding and larval development of mola, Amblypharyngodon mola, (Hamilton 1822) from different regions of Bangladesh. In $6^{\text {th }}$ biennial fisheries conference and research fair 2014. Dhaka: Bangladesh.

Sarkar, D. (2008). Lattice: Multivariate data visualization with $R$. New York: Springer.

Smith, L. C., Ramakrishnan, U., Ndiaye, A., Haddad, L., \& Martorell, R. (2003). The importance of women's status for child nutrition in developing countries. International food policy research institute. http://www.ifpri.org/sites/default/files/publications/rr131.pdf. Accessed 15 July 2015.

Sultana, P., \& Thompson, P. (2008). Gender and local floodplain management institutions: A case study from Bangladesh. Journal of International Development, 20, 53-68.

Suresh, V. R., Biswas, B. K., Vinci, G. K., Mitra, K., \& Mukherjee, A. (2007). Biology of Amblypharyngodon mola (Hamilton) from a floodplain wetland. West Bengal. Indian Journal of Fisheries., 54, 155-161.

Thilsted, S. H. (2012a). Improved management, increased culture and consumption of small fish species can improve diets of the rural poor. In Biodiversity and sustainable diets united against hunger. FAO Headquarter: Rome. FAO.

Thilsted, S. H. (2012b). The potential of nutrient-rich small fish species in aquaculture to improve human nutrition and health. In RP Subasinghe, JR Arthur, DM Bartley, SS De Silva, M Halwart, N Hishamunda, CV Mohan, P Sorgeloos, eds. Farming the Waters for People and Food. Proceedings of the Global Conference on
Aquaculture 2010, Phuket, Thailand. 22-25 September 2010. pp 57-73. FAO, Rome and NACA, Bangkok. ftp://ftp.fao.org/FI/ DOCUMENT/aquaculture/aq2010_11/root/global_conference/ proceeding_global_conference.pdf. Accessed 18 Mar 2013.

Thilsted, S. H., \& Wahab, M. A. (2014a). Nourishing Bangladesh with micronutrient-rich small fish. CGIAR research program on aquatic agricultural systems. Penang, Malaysia. Policy Brief: AAS-201408. http://pubs.iclarm.net/resource_centre/AAS-2014-08.pdf. Accessed 20 May 2015.

Thilsted, S. H., \& Wahab, M. A. (2014b). Polyculture of carps in ponds and ponds connected to rice fields. CGIAR Research Program on Aquatic Agricultural Systems, Penang, Malaysia. Brochure: AAS2014-06. http://pubs.iclarm.net/resource centre/AAS-2014-06.pdf. Accessed 2 Nov 2014.

Thilsted, S. H., \& Wahab, M. A. (2014c). Pond polyculture technologies combat micronutrient deficiencies and increase household income in Bangladesh. CGIAR Research Program on Aquatic Agricultural Systems, Penang, Malaysia. Policy Brief: AAS-2014-09. http://pubs. iclarm.net/resource centre/AAS-2014-09.pdf. Accessed 2 Nov 2014.

Thilsted S. H., \& Wahab, M. A. (2014d). Production and conservation of nutrient-rich small fish (SIS) in ponds and wetlands for nutrition security and livelihoods in South Asia. Proceedings of a World Bank/SAFANSI funded regional workshop on small fish and nutrition. Dhaka, Bangladesh.1st - 2nd March 2014, pp 47. http://pubs. iclarm.net/resource_centre/WF-3728.pdf. Accessed 2 Nov 2014.

Thilsted, S. H., Thorne-Lyman, A., Subasinghe, R., Webb, P., Bogard, J. R., Phillips, M. J., \& Allison, E. H. (2016). Sustaining healthy diets: The role of capture fisheries and aquaculture for improving nutrition in the post-2015 era. Food Policy, 61, 126-131. doi:10.1016/j. foodpol.2016.02.005.

Victora, C. G., Adair, L., Fall, C., Hallal, P. C., Martorell, R., Richter, L., \& Sachdev, H. S. (2008). Maternal and child undernutrition: Consequences for adult health and human captial. The Lancet, 371, 340-357.

Wahab, M. A., Alim, M. A., \& Milstein, A. (2003). Effects of adding the small fish punti (Puntis sophore Hamilton) and/or mola (Amblypharyngodon mola Hamilton) to a polyculture of large carp. Aquaculture Research, 33, 149-163.

Wahab, M. A., Kadir, A., Milstein, A., \& Kunda, M. (2011). Manipulation of species combination for enhancing fish production in polyculture systems involving major carps and small indigenous fish species. Aquaculture, 321, 289-297.

Webb, P. (2013). Impact pathways from agricultural research to improved nutrition and health: literature analysis and research priorities. FAO and WHO. ICN2 Second International Conference on Nutrition. http://www.fao.org/3/a-as573e.pdf. Accessed on 16 Aug 2014

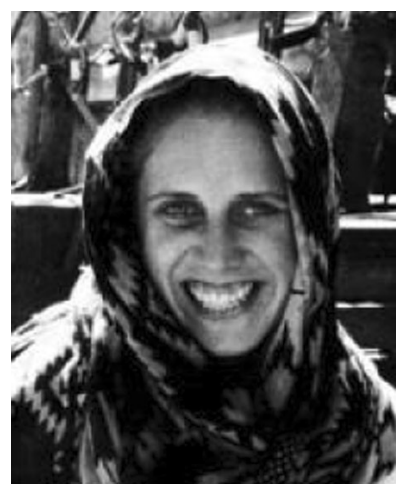

Dr. Sarah Castine is an Australian consultant with both national and international consultancies in environmental impact assessment and improvements to human health through improved aquaculture production. She held a two year post-doctoral position at WorldFish (CGIAR) and completed an industry-based Ph.D. in aquaculture wastewater treatment from James Cook University in 2012. An outcome of the Ph.D. work was that Australia's largest prawn farm upgraded their wastewater treatment system to improve bacterial and algal treatment of waste nutrients. This ensured that the farm met the new 'zero net discharge' 
regulation and that they were approved for extension of their lease area. Underpinning both her Ph.D. and post-doctoral work was the need to enhance food production while reducing the strain on natural resources and improving human health. Together this work has demonstrated the great potential and many avenues for operating sustainably and she is an advocate for environmental conservation while encouraging the growth of sustainable and healthy food production systems.

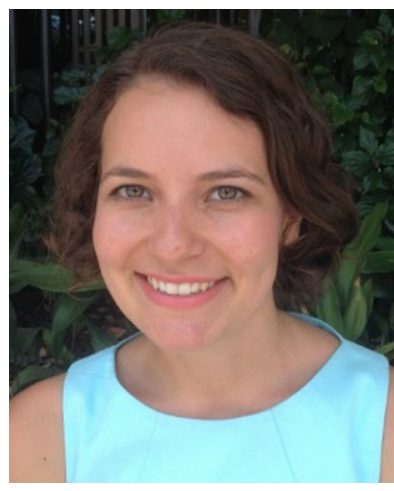

Dr. Jessica Bogard completed her Ph.D. at The University of Queensland, School of Public Health. She is an accredited practising dietitian (APD) with an interest in agricultural policy and research linking fisheries, nutrition and health. Her field experience has been focused in South Asia and the Pacific with WorldFish (CGIAR). Her Ph.D. research investigated the contribution of fish to nutrition and health, particularly for women and young children, providing evidence for a shift in food policy away from a narrow focus on quantity and productivity towards one which promotes diversity and nutritional quality.

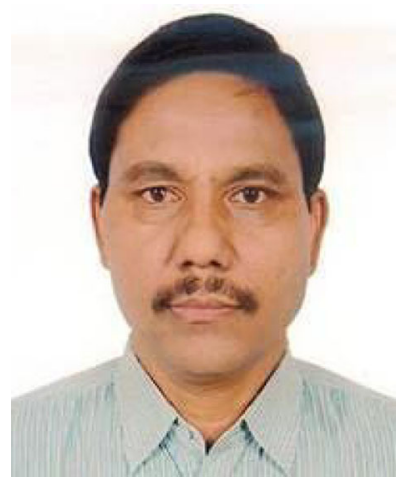

Dr. Benoy Kumar Barman is a senior scientist at WorldFish, Bangladesh and South Asia and is a specialist in the field of aquaculture and aquatic resources management. With more than 30 year's experience working in Bangladesh, Vietnam, Thailand, Nepal and India, Dr. Barman is specialised in aquaculture and gender. Prior to joining WorldFish in 2002, he worked from 1983 as the Bangladesh Civil Service (Fisheries) Cadre officer in the Department of Fisheries, Government of Bangladesh where he was responsible for promoting aquaculture and aquatic resources management to benefit the poor.

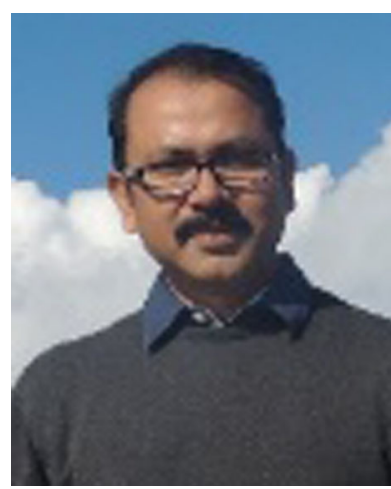

Dr. Manjurul Karim has more than 20 year's research and development experience, including project design and management, aquaculture and integrated farming systems, productivity, livelihoods, monitoring and evaluation process, participatory action, aquaculture value chain, and community-based development interventions in Bangladesh. With a focus on livelihoods and integrated agriculture-aquaculture (IAA) and natural resources, he subsequently gained coordination and leadership skills working with a range of national and international organisations and projects focusing on transfer of technology, and capacity building of farming communities to eliminate poverty. He has designed and conducted project impact assessments, feasibility studies, needs assessment as well as Rapid Situation Assessment (RSA), and has an in-depth knowledge and understanding of participatory technology development.

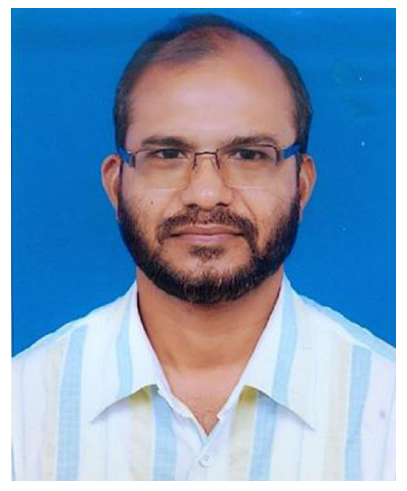

Mr. Md. Mokarrom Hossain is project leader of CSISA-BD and SUCHANA at WorldFish, Bangladesh and South Asia office. His role includes designing and promoting women-friendly, household-based food production technologies, as well as nutritionfocused aquaculture and horticulture systems. He is completing his Ph.D. at the Bangladesh Agricultural University, investigating low-cost protein alternative feeds for prawn and tilapia farming. Previous work includes programme manager, BRAC where he developed tailored aquaculture technology packages through adaptive research for income and employment generation for poor and marginalized groups in rural Bangladesh. Subsequently, up to 2009, he was based at BRAC head office as sector specialist (Fisheries), general manager (Fisheries Enterprise), and programme manager (Agro-production). In 2002, BRAC won a gold medal award from the Government of Bangladesh for its contribution to the fisheries sector development, under the leadership of Mr. Hossain. After BRAC, he worked as general manager of a sea-food business company, WAB Trading International, in Bangladesh. 


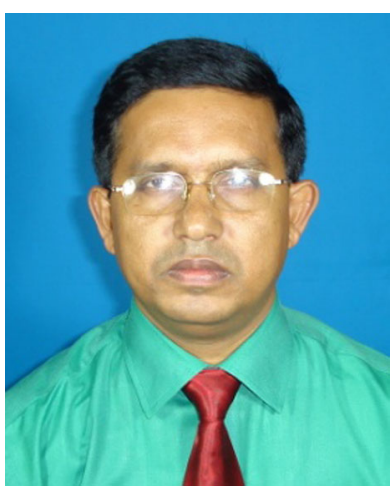

Dr. Mrityunjoy Kunda has worked for over 20 years in the fisheries sector in Bangladesh and also has experience from India, Nepal, Cambodia and Myanmar. Currently, he is Associate Professor, Department of Aquatic Resource Management, Faculty of Fisheries, Sylhet Agricultural University, Bangladesh. Previously, he worked as a scientist at WorldFish, Bangladesh and South Asia office, and farm manager of a fish seed multiplication farm and district fishery officer, Department of Fisheries, Government of Bangladesh. As manager, he was responsible for operations and planning of a fish seed farm in Barguna. Twenty-seven of his research papers are published in international and national journals and he has presented 13 scientific papers at international and national seminars. He holds a Ph.D. in Fisheries Management from the Bangladesh Agricultural University and has carried out five research projects as principal investigator. He has expertise in integrated fish farming systems and promotion of small indigenous fish species (SIS)..

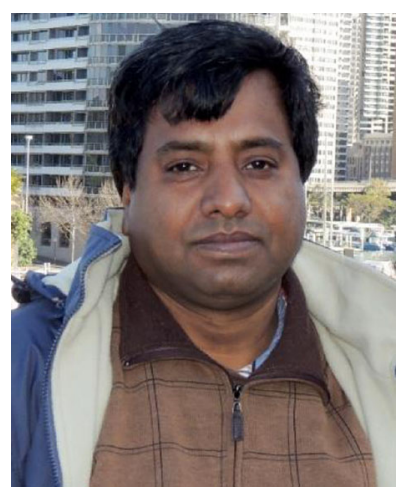

Mr. A.B.M. Mahfuzul Haque is a Ph.D. scholar at Wageningen University, The Netherlands. His $\mathrm{Ph}$.D. research identifies institutional arrangements and their influence on power relations in the management of communitybased fisheries. His research aims to determine the impact of community-based fisheries management on communities and households and provide evidence for developing policies to better utilize fish resources and improve fish-based livelihoods of the people living in and around the floodplains of Bangladesh. Mr. Haque's research interests include community-based fish culture, integrated agriculture-aquaculture technology adoption and dissemination, integrated floodplain management, social and natural resources in flood-prone ecosystems, and monitoring and impact assessment. Eleven of his research papers are published in international and national journals. Mr. Haque is presently working as a monitoring and evaluation specialist at WorldFish, Bangladesh and South Asia office.

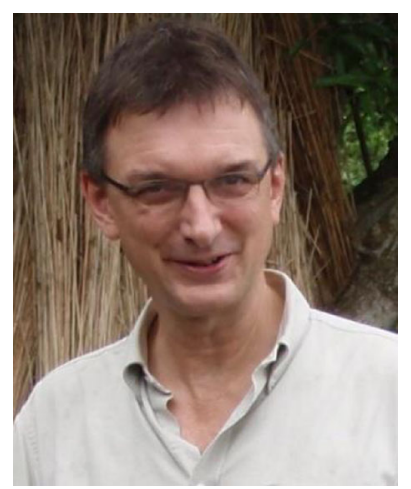

Dr. Michael Phillips is Director of the Aquaculture and Genetic Improvement Discipline at WorldFish. Recognised as a global leader in aquaculture research, Michael joined WorldFish in 2008 where he has since developed a wide portfolio of research on sustainable aquaculture. Previously, he served as Programme Manager at the Network of Aquaculture Centers in Asia-Pacific (NACA) where he managed the organisations' aquaculture research and development programmes. Michael holds a Ph.D. in Aquaculture and Fish Behaviour from the University of Stirling and a B.Sc. in Biological Sciences from University of Lancaster, United Kingdom.

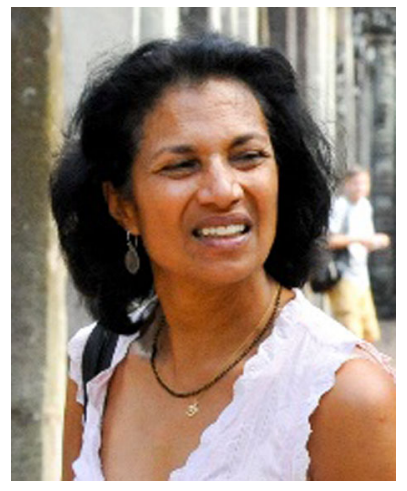

Dr. Shakuntala Haraksingh Thilsted is senior nutrition scientist at WorldFish. She represents WorldFish in the CGIAR Research Program (CRP) on Agriculture for Nutrition and Health $(\mathrm{A} 4 \mathrm{NH})$ and contributes to the CRPs on Aquatic Agricultural Systems (AAS) and Livestock and Fisheries (L\&F). Her broad area of research and expertise is food-based strategies for improved food and nutrition security in low-income countries. She has carried out work in Bangladesh, Cambodia, West Bengal and Nepal, together with government institutions, universities and NGOs, focusing on the potential of nutrient-rich small fish in combating and preventing vitamin and mineral deficiencies, in particular, vitamin A, iron, zinc and calcium, especially in women and children. She has an intensive global, regional and national network of research partners and collaborators in the area of agriculture nutrition linkages and is actively engaged in setting the global agenda for nutrition-sensitive aquatic agricultural systems. She holds a Ph.D. from The Royal Veterinary and Agricultural University, Denmark and a B.Sc. from the University of the West Indies. 